\title{
UPAYA PENANGGULANGAN DAN PERLINDUNGAN HUKUM TERHADAP PERMASALAHAN ANAK DI KOTA BENGKULU
}

\author{
Helda Rahmasari \\ Fakultas Hukum Universitas Bengkulu \\ e-mail : heldarahmasari@unib.ac.id
}

\begin{abstract}
Issues of children in Indonesia are very alarming, the children become victims of crime that is done by an adult, experience a bad treatment even the children become a criminal themselves. As a country that is constantly evolving and advancing, Indonesia faces many problems related to children, including Bengkulu Province, one of many provinces that is growing. Bengkulu city as a part of Bengkulu province also faces the issues of children that occur lately. This research aims to inventory the issues of children in the city of Bengkulu in order to obtain more comprehensive data regarding the issues of children in Bengkulu city. The research is carried out within a period of one year (2016) that is carried out through the following stages: Preparation includes administration of research, collecting and reviewing of secondary data, and arranging the instruments as focus of interview for primary data collection in the field, collecting data through observation, questionnaires, and interviews (indepth interview) to obtain primary data in the form of data and information that relate to the issues of research, literature research to obtain and to review the secondary data.Collecting data and legal materials are done by identifying, inventorying, and making notes on legislation, legal literature, scientific works of the law, report of the legal research, legal journals, legal documents such as law dictionary and so forth, which relate to the issues and the protection of children. Checking and validating data use coding techniques and editing of data.The drafting of concept of inventory result about issues of children and also the causing faktor and the effort that is made in handling the issues of children that are analyzed by using qualitative analysis in the form of description of children issues in Bengkulu city with inductive-deductive thinking method and otherwise. The results show that there are issues of children in Bengkulu city, such as the children that face the Law (ABH), street children, working children, children with disabilities, abandoned children, the children as a beggar, and school dropout children. Efforts that have been made by Sosial Department of Bengkulu city together with The Civil Service Police Unit are to catch the street children.The street children are caught and put into the orphanage. For the children that face the Law (ABH), Sosial Department assisted with SAKTI PEKSOS which is a sosial workers from the Ministry of Sosial Affairs of Republic of Indonesia. Currently the Sosial Department of Bengkulu Province overcomes the issues of abandoned children cooperating with institutions such as LKSK (institution of children sosial welfare ). The efforts made BPMPAKB for ABH is to provide advocacy and assistance.
\end{abstract}

Keywords: Attempt, Treatment, Legal Protection, Issues, Children

Helda Rahmasari, Upaya Penanggulangan dan Perlindungan Hukum Terhadap Permasalahan Anak di Kota Bengkulu 


\begin{abstract}
ABSTRAK
Tingkat permasalahan anak di Indonesia sangat memprihatinkan, anak-anak menjadi korban kejahatan orang dewasa, mengalami perlakuan salah maupun anak-anak menjadi pelaku tindak pidana. Sebagai sebuah negara yang terus berkembang dan semakin maju, Indonesia menghadapi banyak permasalahan yang berkaitan dengan anak, termasuk Provinsi Bengkulu yang merupakan salah satu provinsi yang sedang berkembang tidak terlepas dari permasalahan anak yang marak saat ini. Kota Bengkulu sebagai bagian dari provinsi Bengkulu tidak terlepas dari permasalahan anak yang terjadi akhir-akhir ini di mana potret permasalahan anak yang dominan terjadi di Kota Bengkulu adalah anak jalanan, anak yang bekerja, anak putus sekolah, dan lain sebagainya. Penelitian ini bertujuan untuk menginventarisasi permasalahan anak di Kota Bengkulu sehingga diperoleh data yang lebih komprehensif mengenai permasalahan anak di Kota Bengkulu. Penelitian ini dilakukan dalam kurun waktu 1 tahun (2016) dilakukan melalui tahapan : Persiapan meliputi administrasi penelitian, pengumpulan data primer maupun sekunder, data primer diperoleh melalui observasi, kuisioner, dan Wawancara (indepth interview). Pengolahan data dilakukan dengan pengecekan dan validasi data menggunakan teknik coding dan editing data. Hasil penelitian dianalisis dengan menggunakan analisis kualitatif berupa pendeskripsian permasalahan anak di Kota Bengkulu dengan metode berpikir deduktif-induktif dan sebaliknya. Hasil penelitian menunjukkan terdapat permasalahan anak di Kota Bengkulu antara lain Anak Berhadapan dengan Hukum $(\mathrm{ABH})$, anak jalanan, pekerja anak, anakanak disabilitas, anak terlantar, anak gepeng, dan anak putus sekolah. Upaya yang telah dilakukan oleh Dinsos kota bersama-sama dengan Satpol PP menjaring anak jalanan untuk kemudian dimasukkan ke dalam panti. Untuk ABH, Dinas Sosial Kota dibantu dengan SAKTI PEKSOS yaitu Pekerja Sosial dari Kementerian Sosial RI. Saat ini Dinas Sosial Provinsi Bengkulu mengatasi anak terlantar bermitra dengan lembaga-lembaga yaitu LKSA (Lembaga Kesejahteraan Sosial Anak). Upaya yang dilakukan BPMPPAKB untuk $\mathrm{ABH}$ adalah dengan memberikan advokasi dan pendampingan.
\end{abstract}

Kata Kunci : Upaya,Penanggulangan, Perlindungan Hukum, Permasalahan, anak

\section{PENDAHULUAN}

\section{Latar Belakang}

Undang-Undang Nomor 23

Tahun 2002 jo Undang-Undang 35

Tahun 2014 tentang Perlindungan

Anak telah menegaskan tanggung

jawab perlindungan anak kepada orang tua, keluarga, masyarakat, pemerintah dan Negara. Pasal 3 Undang-Undang 23 Tahun 2002 mengatur tujuan perlindungan anak yang berbunyi :

"Perlindungan anak bertujuan untuk menjamin terpenuhinya hak-hak anak agar dapat hidup,

Helda Rahmasari, Upaya Penanggulangan dan Perlindungan Hukum Terhadap Permasalahan Anak di Kota Bengkulu 
tumbuh, berkembang dan berpartisipasi secara optimal sesuai dengan harkat dan martabat kemanusiaan serta mendapat perlindungan dari kekerasan dan diskriminasi, demi terwujudnya anak Indonesia yang berkualitas, berakhlak mulia dan sejahtera.

Sebagaimana diketahui, tingkat permasalahan anak di Indonesia sangat memprihatinkan, anak-anak menjadi korban kejahatan orang dewasa, mengalami perlakuan salah maupun anakanak menjadi pelaku tindak pidana. Sebagai sebuah Negara yang terus berkembang dan semakin maju, Indonesia menghadapi banyak permasalahan yang berkaitan dengan anak, termasuk Provinsi Bengkulu kuhususnya Kota Bengkulu yang merupakan salah satu bagian dari Provinsi Bengkulu, tidak terlepas dari fenomena permasalahan anak.

Data Ditjen Pemasyarakatan Juni 2014 menujukan 2.060 anak (1.891 laki-laki, 169 perempuan) ditahan di berbagai institusi penahanan yang tersebar di Indonesia dan masih dalam proses peradilan. Jumlah narapidana anak di Indonesia 3.379 anak (3.095 lakilaki, 284 perempuan) sudah pada proses peradilan dinal (putusan peradilan). Angka ini meningkat dibandingkan populasi tahanan anak pada tahun 2011. Komisi Nasional Perlindungan Anak (LSM Komnas PA) melaporkan bahwa terdapat 1.851 pengaduan anak yang berhadapan dengan hukum (pencurian, kekerasan, pemerkosaan, narkoba, perjudian dan penganiayaan). ${ }^{1}$

Berdasarkan penelitian yang telah dilakukan oleh peneliti maupun pihak lain, permasalahan anak di Kota Bengkulu saat ini berada pada taraf yang mengkhawatirkan. Salah satunya untuk tindak pidana incest Bengkulu merupakan Provinsi dengan angka tertinggi. ${ }^{2}$ Selain itu, terdapat permasalahan lain seperti anak-anak yang terpaksa bekerja membantu orang tuanya dengan

1 FHA Suharto, Budhi Wibhawa \& Eva Nuriyah Hidayat, Interaksi di dalam Keluarga Dengan Anak Berhadapan dengan Hukum di Panti Sosial Putra Bambu Apus Jakarta, Prosiding-KS : Riset \& PKM, Volume 3 Nomor 3, ISSN : 2442-4480, Hal. 350. Diakses tanggal 16 Juli 2016 dari website : http://fisip.unpad.ac.id/jurnal/index.ph p/prosiding/article/view/202/ 186.

2 Bengkulu Ekspress 2 November 2015, Incest Bengkulu Peringkat Satu, diunduh tanggal 16 Maret 2016, dari http://bengkuluekspress.com/incestbengkulu-peringkat-satu/.

Helda Rahmasari, Upaya Penanggulangan dan Perlindungan Hukum Terhadap Permasalahan Anak di Kota Bengkulu 
menjadi penambang batu bara. ${ }^{3}$ Permasalahan lainnya yang tak kalah mengkhawatirkan adalah jumlah anak terlantar dan anak jalanan yang semakin bertambah dari waktu ke waktu, ${ }^{4}$ dan penelitian terbaru yang dilakukan peneliti tahun 2014 menunjukkan adanya Pelajar yang masih berstatus anak menjadi seorang PSK di balik seragam sekolahnya. ${ }^{5}$ Permasalahan anak tersebut di atas menunjukkan masih banyaknya pelanggaran yang terjadi terhadap hak anak, yang tentu saja harus dilakukan sebuah upaya untuk menanggulanginya. Permasalahanpermasalahan tersebut hanya merupakan sebagian kecil saja dari permasalahan anak yang ada di

3 Helda Rahmasari, Pemenuhan hak tumbuh kembang anak di wilayah pesisir kota Bengkulu dalam perspektif Undang-Undang Nomor 23 tahun 2002, Laporan Penelitian Dosen Pemula Fakultas Hukum Universitas Bengkulu, 2013.

4 Freddy Ferdinant Sanses, Tinjauan Yuridis-Sosiologis Pertanggungjawaban Pidana Pemerintah Kota Bengkulu dan Orangtua Dalam Penghapusan Eksploitasi Ekonomi Terhadap Anak, skripsi Fakultas Hukum Universitas Bengkulu, 2015, hlm. 3.

5 Helda Rahmasari, kebijakan pemerintah kota dalam penanggulangan keberadaan pekerja seks komersial (psk) dari kalangan pelajar di kota bengkulu (suatu kajian kebijakan dan kriminologi), Penelitian BOPTN Fakultas Hukum Universitas Bengkulu, 2014. Helda Rahmasari, Upaya Penanggulangan dan Perlindungan Hukum Terhadap Permasalahan Anak di Kota Bengkulu
Kota Bengkulu dan memungkinkan masih terdapat banyak permasalahan anak lainnya yang ada di Kota Bengkulu.

$$
\text { Penelitian }
$$
ini lebih menekankan pada inventarisasi permasalahan anak di Kota Bengkulu beserta penyebabnya dan upaya untuk mengatasi permasalahan tersebut. Berbeda dari penelitian terdahulu, penelitian ini bertujuan memperoleh data dan mengkaji permasalahan anak secara lebih luas.

\section{Permasalahan}

a. Permasalahan anak apa saja yang ada di Kota Bengkulu dan Faktor apa yang mempengaruhi munculnya permasalahan anak di Kota Bengkulu?

b. Upaya apa yang dilakukan untuk menanggulangi permasalahan anak di Kota Bengkulu?

\section{METODE PENELITIAN}

Penelitian hukum empiris (non doctrinal) dengan pendekatan sociallegal research ini merupakan kajian terhadap hukum dengan menggunakan pendekatan ilmu hukum dan ilmu 
sosial. Lokasi penelitian di Kota Bengkulu dengan pertimbangan, berdasarkan observasi dan pra penelitian, menunjukkan adanya permasalahan anak di Kota Bengkulu. Populasi dan sampel terdiri dari instansi pemerintah yang terkait dengan masalah perlindungan anak. Dalam hal ini Dinas Kesejahteraan Sosial Provinsi Bengkulu, Dinas Sosial Kota Bengkulu, Badan Pemberdayaan Perempuan dan Perlindungan Anak Provinsi Bengkulu dan Badan Pemberdayaan Masyarakat Perempuan Perlindungan Anak dan Keluarga Berencana Kota Bengkulu. LSM atau lembaga non pemerintah yang bergerak di bidang perlindungan anak yaitu Yayasan PUPA Bengkulu dan Cahaya Perempuan WCC Bengkulu. Demikian juga anak yang menghadapi beberapa permasalahan. Sumber data adalah data primer dan data sekunder. Pengumpulan data dengan melakukan wawancara kepada responden di lapangan dan data sekunder denganstudi pustaka. Selanjutnya dilakukan pengecekan dan validasi data dengan menggunakan teknik coding dan editing data. Hasil validasi data dianalisis dengan menggunakan analisis kualitatif berdasarkan metode berpikir deduktif-induktif dan sebaliknya.

\section{TINJAUAN PUSTAKA}

\section{Tinjauan tentang anak}

Anak merupakan bagian yang tidak terpisahkan dari kehidupan suatu masyarakat. Anak adalah makhluk sosial seperti juga orang dewasa. Anak membutuhkan orang lain untuk dapat membantu mengembangkan kemampuanya, karena anak lahir dengan segala kelemahan. Oleh karena itu tanpa orang lain anak tidak mungkin dapat mencapai taraf kemanusiaan yang normal. Pengertian anak secara umum dipahami masyarakat adalah keturunan kedua setelah ayah dan ibu. Sekalipun dari hubungan yang tidak sah dalam kaca mata hokum, tetap dinamakan anak, sehingga pada definisi ini tidak dibatasi dengan usia. 6

353.

Helda Rahmasari, Upaya Penanggulangan dan Perlindungan Hukum Terhadap Permasalahan Anak di Kota Bengkulu 
Batas usia anak memberikan pengelompokkan terhadap seseorang untuk dapat disebut sebagai seorang anak. Batas usia anak adalah pengelompokkan usia maksimum sebagai wujud kemampuan anak dalam status hukum, sehingga anak tersebut beralih status menjadi usia dewasa atau menjadi seorang subjek hukum yang dapat bertanggungjawab secara mandiri terhadap perbuatan-perbuatan dan tindakan-tindakan hukum yang dilakukan anak itu. Untuk dapat disebut sebagai anak, maka orang itu harus berada pada batas usia bawah atau usia minimum nol (0) tahun terhitung mulai dalam kandungan sampai dengan batas usia atas atau usia maksimum 18 (delapan belas) tahun sesuai dengan ketentuan hukum yang berlaku. ${ }^{7}$

$$
\text { Pengertian dan batasan }
$$

usia anak dalam peraturan perundang-undangan baik internasional maupun nasional antara lain :

\section{a. Konvensi Hak Anak (Convention On The Rights Of The Child)}

Pemerintah Indonesia meratifikasi Konvensi Hak Anak dengan mengeluarkan Keputusan Presiden Nomor 36 Tahun 1990, tertanggal 25 Agustus 1990 tentang Pengesahan Konvensi Hak Anak. Oleh karena itu, Keppres No. 36 Tahun 1990 yang mengesahkan KHA tersebut secara yuridis telah mengikat negara Indonesia sebagai negara peserta (state party) dalam Konvensi Hak Anak.

Pengertian tentang anak dalam Konvensi Hak-Hak Anak diatur dalam Pasal 1 yang berbunyi : "seorang anak adalah setiap manusia yang berusia di bawah 18 tahun kecuali, berdasarkan undang-undang yang berlaku bagi anak-anak, kedewasaan dicapai lebih cepat"8
7 Maulana Hassan Wadong, Pengantar Advokasi dan Hukum Perlindungan Anak, Grasindo, Jakarta, 2000, hlm. 24.

Helda Rahmasari, Upaya Penanggulangan dan Perlindungan Hukum Terhadap Permasalahan Anak di Kota Bengkulu
8 Muhammad Joni, dan Zulchaina Z. Tanamas, Aspek Hukum Perlindungan Anak dalam Perspektif Konvensi Hak Anak, PT. Citra Aditya Bakti, Bandung, 1999, hlm. 135. 
b. Konvensi ILO Nomor 182 Tentang Pelarangan dan Tindakan Segera Untuk Penghapusan Bentuk-Bentuk Pekerjaan Terburuk Untuk Anak

Tidak berbeda dengan

Konvensi Hak Anak, Konvensi ILO 182 yang disahkan melalui Undang-Undang Nomor 1 Tahun 2000, dalam Pasal 2 menegaskan, bahwa istilah anak dalam Konvensi ini berarti semua orang yang berusia di bawah 18 tahun.

c. Undang-Undang Nomor 23 Tahun 2002 Tentang Perlindungan Anak jo Undang-Undang Nomor 35 tahun 2014.

Pengertian anak dalam Undang-Undang Nomor 23 Tahun 2002, diatur dalam Pasal 1 angka 1, pasal tersebut menyebutkan, bahwa anak adalah seseorang yang belum berusia 18 (delapan belas) tahun, termasuk anak yang masih dalam kandungan. ${ }^{9}$

\section{d. Undang-Undang Nomor 4 Tahun 1979 Tentang Kesejahteraan Anak}

$$
\text { Pasal } 1 \text { angka } 2
$$
menyebutkan, bahwa anak adalah seseorang yang belum

$9 \quad$ Undang-Undang Perlindungan Anak (UU RI NO. 23 Th. 2002), hlm 3.

Helda Rahmasari, Upaya Penanggulangan dan Perlindungan Hukum Terhadap Permasalahan Anak di Kota Bengkulu mencapai umur 21 (dua puluh satu) tahun dan belum pernah kawin.

Penjelasan Pasal 1 angka 2 Undang-Undang Nomor 4 Tahun 1979 menyebutkan, bahwa batas umur 21 (dua puluh satu) tahun ditetapkan oleh karena berdasarkan pertimbangan kepentingan usaha kesejahteraan sosial, tahap kematangan sosial, kematangan pribadi, dan kematangan mental seseorang anak dicapai pada umur tersebut. 10

Batas umur 21 (dua puluh satu) tahun tidak mengurangi ketentuan batas dalam peraturan perundangundangan lainnya, dan tidak pula mengurangi kemungkinan anak melakukan perbuatan sejauh mempunyai kemampuan untuk itu berdasarkan hukum yang berlaku.

\section{e. Undang-Undang Nomor 39 Tahun 1999 Tentang Hak Asasi Manusia}

Pasal 1 angka 5 menyebutkan pengertian anak, 
bahwa anak adalah manusia yang berusia di bawah 18 (delapan belas) tahun dan belum menikah, termasuk anak yang masih dalam kandungan apabila hal tersebut adalah demi kepentingannya. ${ }^{11}$

\section{Perlindungan hukum Hak Anak}

Menurut Supeno

sebagaimana dikutip oleh Febry Hizba Ashhaina Suharto, dkk, anak mempunyai hak-hak yang secara spesifik berbeda dengan manusia dewasa karena kondisi fisik dan mentalnya yang belum stabil. Dalam banyak hal, anakanak memerlukan perlakuan dan perlindungan khusus, terutama terhadap perbuatan yang bisa merugikan perkembangannya maupun masyarakat. Anak membutuhkan pihak lain seperti keluarga, masyarakat, pemerintah dan negara untuk mendukung tumbuh kembang anak secara wajar. Kesejahteraan dan perlindungan anak merupakan persoalan yang serius karena terkait dengan kelangsungan hidup sebuah masyarakat dan rancang bangun sosial masa depan sebuah Negara. ${ }^{12}$

Aspek hukum perlindungan terhadap hak anak telah diatur di beberapa peraturan baik internasional maupun nasional yang merupakan cermin bahwa begitu pentingnya permasalahan perlindungan terhadap hak anak sebagai salah satu penghormatan terhadap hak asasi manusia.

Instrument hukum dalam perlindungan hak anak adalah Konvensi Hak Anak yang diratifikasi oleh Indonesia melalui Keputusan Presiden Nomor 36 Tahun 1990. Adapun hak anak menurut Konvensi Hak Anak Jo Keputusan Presiden Nomor 36 Tahun 1990 adalah sebagai berikut :

1. Hak Hidup (Survival Rights) meliputi :

a. Anak mempunyai hak untuk hidup (Pasal 6);

b. Hak atas kehidupan yang layak atas kesehatan dan pelayanan kesehatan (Pasal 24).

11 UU RI No. 39 Th. 1999 tentang Hak Asasi Manusia, Sinar Grafika, Jakarta, 2000, hlm. 3. 
2. Hak

Perlindungan

Mendapatkan

(Protection

Rights), meliputi :
a. Larangan
deskriminasi anak
b. Larangan eksploitasi anak

3. Hak untuk Tumbuh Kembang

(Development Rights), meliputi antara lain:

a. Hak mendapat pendidikan baik formal maupun informal (Pasal 28 dan Pasal 29)

b. Hak memperoleh informasi (Pasal 7)

c. Hak bermain

d. Hak menikmati norma kesehatan tertinggi (Pasal 24).

4. Hak

berpasrtisipasi

(Participation Rights), meliputi :

a. Hak anak untuk menyatakan pendapat secara bebas (Pasal 13);

b. Hak anak untuk berkumpul (Pasal 15). ${ }^{13}$

Undang-Undang Nomor 23

Tahun 2002 Jo Undang-

Undang Nomor 35 Tahun 2014

Tentang Perlindungan Anak

merupakan payung hukum

dalam perlindungan anak,

menjelaskan bahwa yang

dimaksud dengan

perlindungan adalah segala

kegiatan untuk menjamin dan

melindungi anak dan hak-

13 Ibid, hal. 133-134

Helda Rahmasari, Upaya Penanggulangan dan Perlindungan Hukum Terhadap Permasalahan Anak di Kota Bengkulu

haknya agar dapat hidup, tumbuh, berkembang dan berpartisipasi, secara optimal sesuai dengan harkat dan martabat kemanusiaan, serta mendapat perlindungan dari diskriminasi.

Selanjutnya dalam Pasal 3 menyebutkan bahwa :

Perlindungan anak bertujuan untuk menjamin terpenuhinya hak-hak anak agar dapat hidup, tumbuh, berkembang, dan berpartisipasi secara optimal sesuai dengan harkat dan martabat kemanusiaan serta mendapat perlindungan dari kekerasan dan diskriminasi demi terwujudnya anak Indonesia yang berkualitas, berakhlak mulia dan sejahtera.

Undang-Undang ini mengatur secara tegas mengenai hak anak dalam Bab III mengenai Hak dan Kewajiban Anak antara lain dalam Pasal 4 sampai Pasal 11. Pasal 4 berbunyi :

Setiap anak berhak untuk dapat hidup, tumbuh, berkembang, dan berpartisipasi secara wajar sesuai dengan harkat dan martabat kemanusiaan, serta mendapat perlindungan dari kekerasan dan diskriminasi.

Undang-Undang Nomor 4 Tahun 1979 tentang 
Kesejahteraan Anak dalam Bab

II Pasal 2 sampai dengan Pasal

9 mengatur hak-hak anak atas

kesejahteraan, sebagai berikut:

1. Hak atas kesejahteraan, perawatan, asuhan dan bimbingan;

2. Hak atas pelayanan;

3. Hak atas pemeliharaan dan perlindungan;

4. Hak atas perlindungan lingkungan hidup;

5. Hak mendapat pertolongan pertama;

6. Hak memperoleh asuhan;

7. Hak memperoleh bantuan;

8. Hak diberi pelayanan dan asuhan;

9. Hak memperoleh pelayanan khusus;

10. Hak mendapat bantuan dan pelayanan ${ }^{14}$

Selanjutnya, di dalam Panduan Program Nasional Bagi Anak Indonesia (PNBAI) 2015 dijelaskan bahwa tujuan umum perlindungan bagi anak adalah untuk menjamin pemenuhan hak-hak kelangsungan hidup, tumbuh kembang, perlindungan dan partisipasi anak. ${ }^{15}$

14 Darwan Prinst, Hukum Anak Indonesia, PT. Citra Aditya Bakti, Bandung, 2003, hlm. 81-82.

15 Panduan Program Nasional Anak Indonesia (PNBAI) 2015, Kementerian Pemberdayaan Perempuan Republik Indonesia, Jakarta, 2004, hlm.29.

Helda Rahmasari, Upaya Penanggulangan dan Perlindungan Hukum Terhadap Permasalahan Anak di Kota Bengkulu
Dalam ketentuan Pasal 3

Undang-Undang Nomor 11

Tahuun 2012 tentang Sistem

Peradilan

Anak

mencantumkan dengan tegas apa saja yang menjadi hak-hak anak dalam peradilan pidana yakni:

a. diperlakukan secara manusiawi dengan memperhatikan

kebutuhan sesuai dengan umurnya;

b. dipisahkan dari orang dewasa;

c. memperoleh bantuan hukum dan bantuan lain secara efektif;

d. melakukan kegiatan rekreasional;

e. bebas dari penyiksaan, penghukuman atau perlakuan lain yang kejam, tidak manusiawi, serta merendahkan derajat dan martabatnya;

f. tidak dijatuhi pidana mati atau pidana seumur hidup;

g. tidak ditangkap, ditahan, atau dipenjara, kecuali sebagai upaya terakhir dan dalam waktu yang paling singkat;

h. memperoleh keadilan di muka pengadilan Anak yang objektif, tidak memihak, dan dalam sidang yang tertutup untuk umum;

i. tidak dipublikasikan identitasnya;

j. memperoleh

pendampingan orang 
tua/wali dan orang yang dipercaya oleh Anak;

k. memperoleh advokasi sosial;

1. memperoleh kehidupan pribadi;

m. memperoleh aksesibilitas, terutama bagi anak cacat;

n. memperoleh pendidikan;

o. memperoleh pelayananan kesehatan; dan

p. memperoleh hak lain sesuai dengan ketentuan peraturan perundangundangan.

\section{Pihak yang Bertanggung Jawab Terhadap Hak Anak}

Di dalam Undang-Undang Nomor 23 Tahun 2002 Jo Undang-Undang Nomor 35 Tahun $2014 \quad$ Tentang Perlindungan Anak ditegaskan bahwa pertanggungjawaban orang tua, keluarga, masyarakat, pemerintah, dan negara merupakan rangkaian kegiatan yang dilaksanakan secara terus-menerus demi terlindunginya hak-hak anak sebagaimana yang diatur di dalam Pasal 20 yang berbunyi:

"Negara, pemerintah, masyarakat, keluarga dan orang tua berkewajiban dan bertanggung jawab terhadap penyelenggaraan perlindungan anak". Permasalahan Anak di Kota Bengkulu
Menurut Wahyu Hartomo Pihak-pihak yang berkewajiban dan bertanggung jawab terhadap pelaksanaan hak anak yaitu :

1. Negara, mendayagunakan seluruh sumberdaya dengan menerbitkan peraturan dan perundang-undangan, menyelenggarakan pembangunan peduli anak

2. Pemerintah menyediakan sarana dan prasarana dalam pelaksanaan perlindungan anak.

3. Masyarakat menciptakan lingkungan dengan mewujudkan hak anak serta mendukung penyelenggaraan peraturan dan perundangundangan.

4. Orang tua mewujudkan semua hak anak. ${ }^{16}$

Menurut Supriyadi W. Eddyono pihak yang bertanggung jawab terhadap hak anak adalah : Orang tua atau keluarga dan masyarakat pada umumnya mempunyai tanggung jawab dalam pemenuhan hak anak. Negara berarti pihak yang diberi mandat untuk mewakili negara untuk menyelenggarakan

16 Wahyu Hartomo, (tanpa tahun), Rakornas Tumbuh Kembang Anak, Plt. Deputi Bidang Tumbuh Kembang Anak Kementerian Pemberdayaan Perempuan dan Perlindungan Anak, www.google.com, Tumbuh Kembang anak, diakses pada tanggal 15 Maret 2013 pukul 19.47 WIB. 
negara, untuk membuat atau mengubah undang-undang dan peraturan-peraturan, untuk merumuskan dan menjalankan kebijakan administratif serta mengatur kehidupan masyarakat. Ini berarti mencakup pihak eksekutif (pemerintah), legislatif dan yudikatif. Dalam Konteks Konvensi Hak Anak, orang tua/keluarga atau keluarga pengganti serta masyarakat dewasa bertanggung jawab (bukan berkewajiban) memenuhi hak anak. ${ }^{17}$

\section{Anak dan permasalahannya}

Anak korban perkosaan, anak-anak yang dilacurkan buruh anak, anak jalanan, pengungsi anak, anak yang ditelantarkan, anak korban kekerasan, dan anak-anak yang membutuhkan perlindungan khusus (Children in Need of Special Protection) sesungguhnya adalah kelompok

17 Supriyadi W. Eddyono, 2005, Pengantar Konvensi Hak Anak (Seri Bahan Bacaan Kursus Ham Untuk Pengacara), Lembaga Studi dan Advokasi Masyarakat, Jakarta, hlm. 5.

Helda Rahmasari, Upaya Penanggulangan dan Perlindungan Hukum Terhadap Permasalahan Anak di Kota Bengkulu

manusia yang rawan diperlakukan salah. Mereka bukan saja sering tidak dipenuhi hak-hak dasarnya dan ditelantarkan, tetapi juga sering dilanggar hak-haknya, diperlakukan kasar dan menjadi korban child abuse. ${ }^{18}$

Berbagai permasalahan anak di Indonesia menunjukkan masih adanya pelanggaran terhadap hak anak. Hal ini memerlukan upaya serius untuk memberikan perlindungan anak, sehingga mereka mampu tumbuh dan berkembang di lingkungan yang aman serta menjamin hak-hak anak. ${ }^{19}$

\section{PEMBAHASAN}

Kota Bengkulu termasuk salah satu wilayah yang mempunyai permasalahan anak yang cukup mengkhawatirkan. Banyaknya anak jalanan di Kota

${ }^{18}$ Bagong Suyanto, Masalah Sosial Anak, Edisi Revisi, Kencana Prenada Media Group, Jakarta, 2010, hlml. 2

19 Laporan Kajian, Analisis Situasi Perlindungan Anak di Provinsi Bengkulu, Kerjasama antara Kementerian Pemberdayaan Perempuan dan Perllindungan Anak Republik Indonesia dan Pusat Studi Gender dan Keluarga Lembaga Penelitian dan Pengabdian Kepada Masyarakat Universitas Bengkulu, 2015, hlm. 13-14. 
Bengkulu yang ada di jalan raya seperti Simpang lima, simpang jam dan tempat-tempat lainnya menunjukkan bahwa ada permasalahan dalam kehidupan anak di Kota Bengkulu. Adanya anak yang bekerja mengikuti orang tuanya menambang batu bara dari siang sampai malam hari dan mereka kehilangan waktu bermain serta istirahat menunjukkan secara nyata pelanggaran terhadap hak anak. Anak-anak yang berhadapan dengan hukum sebagai pelaku maupun korban tindak pidana tidak kalah pentingnya untuk menjadi perhatian karena perlakuan terhadap anak sebagai pelaku terkadang masih disamakan dengan perlakuan terhadap pelaku tindak pidana dewasa, hal ini menunjukkan masih kurangnya perlindungan terhadap anak itu sendiri meskipun anak berstatus sebagai pelaku tindak pidana. Fakta yang lebih mengkhawatirkan adanya anak-anak yang berstatus pelajar menjadi seorang PSK, dan masih banyak permasalahan anak lainnya yang belum terdata secara komprehensif.

Berdasarkan penelitian lapangan yang dilakukan terhadap anak-anak yang mengalami permasalahan di Kota Bengkulu, diperoleh data bahwa permasalahan anak yang terjadi di Kota Bengkulu antara lain menjadi pengamen, penjual Koran, penjual kantong kresek dan es keliling di pasar, mengumpulkan kardus, menjadi pemulung, dan tukang semir. Dari potret permasalahan tersebut dapat dirinci bahwa permasalahan anak yang terjadi adalah adanya pekerja anak, dan anak jalanan. Adapun faktorfaktor yang menyebabkan terjadinya permasalahan anak tersebut adalah kurangnya perhatian orang tua, seringnya orang tua berlaku kasar, broken home, ekonomi orang tua, putus sekolah, dan faktor pergaulan (karena terpengaruh teman).

Berdasarkan hasil wawancara dengan Kepala Seksi Rehabilitasi Sosial Dinas sosial Kota Bengkulu diperoleh keterangan bahwa permasalahan anak di Kota Bengkulu yang

Helda Rahmasari, Upaya Penanggulangan dan Perlindungan Hukum Terhadap Permasalahan Anak di Kota Bengkulu 
terdata pada Dinas Sosial Kota Bengkulu pada umumnya adalah permasalahan Anak Berhadapan dengan Hukum (ABH), anak jalanan, pekerja anak, dan anak disabilitas (berkebutuhan khusus). Permasalahan yang paling dominan yang ditangani oleh Dinas Sosial Kota Bengkulu adalah permasalahan anak jalanan.

Menurut ibu Nur Apiha, faktor yang menyebabkan munculnya permasalahan anak seperti disebutkan di atas antara lain adalah karena faktor pendidikan dari dalam keluarga terutama orang tua yang harusnya menanamkan nilai mental dan agama sedini mungkin, sehingga anak dapat terhindar dari permasalahanpermasalahan tersebut terutama permasalahan anak jalanan dan pekerja anak. Adapun upaya yang dilakukan oleh Dinas sosial Kota Bengkulu dalam mengatasi atau menanggulangi permasalahan anak tersebut yaitu bersama-sama dengan Satpol PP menjaring anak jalanan yang tersebar tempatnya di Kota Bengkulu. Dimana anak jalanan yang terjaring tersebut dimasukkan ke dalam panti. Untuk ABH, Dinsos Kota dibantu dengan SAKTI PEKSOS yang mana SAKTI PEKSOS ini merupakan Pekerja Sosial dari Kementerian Sosial RI. Untuk Kota Bengkulu memiliki 5 orang SAKTI PEKSOS. Sehingga untuk $\mathrm{ABH}$, SAKTI PEKSOS ini yang melakukan atau memberikan pendampingan. SAKTI PEKSOS ini berkewajiban memberikan laporan mingguan dan bulanan kepada Dinas Sosial Kota mengenai $\mathrm{ABH}$ yang mereka dampingi. Program Dinas Sosial Kota ke depan berpedoman pada program yang telah ada di Kemensos RI. Untuk rumah singgah, Sudah lama Dinsos merencanakannya namun belum terealisasi sampai saat ini. Dinsos Kota selalu berkoordinasi dengan DInsos Provinsi dalam hal pembinaan, dan pendampingan ABH. Untuk anak disabilitas ada bagian tersendiri yang menaungi hal tersebut yaitu Forum Anak dengan Kecacatan. Kurang lebih 5 tahun forum ini telah ada dimana dananya berasal

Helda Rahmasari, Upaya Penanggulangan dan Perlindungan Hukum Terhadap Permasalahan Anak di Kota Bengkulu 
langsung dari Kementerian Sosial RI.

\begin{tabular}{lrr}
\multicolumn{2}{c}{ Berdasarkan } & hasil \\
wawancara dengan & Kasi \\
Rehabilitasi & Sosial Anak & pada \\
Dinas Kesejahteraan Sosial
\end{tabular}
Provinsi Bengkulu, permasalahan anak yang terdata pada Dinas Sosial Provinsi Bengkulu adalah $\mathrm{ABH}$ (Korban) dimana permasalahan ini ditangani oleh SAKTI PEKSOS sama seperti halnya Dinas Sosial Kota, sedangkan untuk anak sebagai pelaku Dinas Kesejahteraan Sosial bekerja sama dengan Balai Pengembangan Anak dan Remaja sub bagian LPKS (Lembaga Penyelenggara Kesejahteraan sosial). Tetapi pendataannya tidak ada karena Dinas Sosial Provinsi fokus terhadap anak terlantar. Permasalahan lainnya adalah anak terlantar, untuk permasalahan ini anak terlantar ada yang ditempatkan di dalam panti maupun di luar panti. Adapun upaya yang dilakukan oleh Dinas Sosial Provinsi Bengkulu dalam mengatasi atau menanggulangi permasalahan anak terlantar ini adalah dengan melakukan koordinasi dan mengawasi anak yang ada diluar dan di dalam panti, untuk anak yang diluar panti dilakukan dengan cara memanggil orang tua anak binaan dalam temu Penguatan Anak dan Keluarga. Dalam program ini ada 2 jenis kegiatan yaitu : Bantuan Anak dan Sosialisasi terhadap anak.

Data permasalahan yang ada di Badan Pemberdayaan Masyarakat Perempuan Perlindungan Anak dan Keluarga Berencana (BPMPPAKB) berdasarkan hasil wawancara dengan Bapak Hasbi selaku Kasubbid Perllindungan dan Perkembangan Anak, permasalahan yang ada di Kota Bengkulu adalah seperti anak gepeng, anak putus sekolah, Anak Berkebutuhan Khusus (ABK/disabilitas) dan Anak Berhadapan dengan Hukum (ABH). Menurut Bapak Hasbi, faktor dominan yang menyebabkan munculnya permasalahan anak tersebut antara lain karena faktor dari orang tua terutama kurangnya pengawasan dari orang tua. Selain itu, menurut Bapak Hasbi, faktor yang mempengaruhi

Helda Rahmasari, Upaya Penanggulangan dan Perlindungan Hukum Terhadap Permasalahan Anak di Kota Bengkulu 
adanya permasalahan anak kepada anak yang menjadi seperti $\mathrm{ABH}$ dalam hal ini sebagai korban termasuk korban pelaku adalah karena faktor kekerasan seksual. Pada tahun lingkungan, etnik dan 2015 terjadi peningkatan kasus perkembangan teknologi. terhadap anak yang menjadi BPMPPAKB Kota melakukan korban, penyebab anak menjadi kerjasama dengan P2TP2A untuk korban antara lain karena memberikan advokasi dan kurangnya perhatian orang tua pendampingan bagi $\mathrm{ABH}$, BPMPAKB juga telah memeberikan andil dalam pembuatan kebijakan mengenai anak, dan untuk yang akan datang BPMPAKB berencana untuk membuat kota layak anak. Berdasarkan hasil wawancara dengan Yayasan Pendidikan Untuk Perempuan dan Anak (PUPA), dalam 3 tahun terakhir PUPA berkontribusi terhadap $\mathrm{ABH}$ dengan melakukan pendidikan keaksaraan di LAPAS, untuk anak sebagai korban dilakukan dengan memberikan advokasi. Selain itu PUPA juga membangun mekanisme perlindungan berbasis sekolah.

Selanjutnya, hasil wawancara Divisi Pelayanan Cahaya Perempuan WCC Bengkulu, bahwa WCC hanya memberikan perlindungan dan faktor pergaulan. WCC memberikan litigasi dari awal sampai pada putusan, sedangkan yang berupa Non-litigasi dilakukan dengan memberikan konseling, pelayanan rujukan, pelayanan rumah aman, dan pelayanan informasi. Upaya yang paling efektif adalah dengan menanamkan pendidikan kepada anak-anak terutama pendidikan moral dan agama. Faktor budaya juga mempengaruhi terjadinya permasalahan anak tersebut seperti budaya patriarki yang membuat perempuan dinomor duakan. WCC tidak memiliki program khusus, namun saat ini WCC melakukan kegiatan pendidikan perempuan. Dinas yang terkait yaitu Dinas Sosial, BMA, MUI, Kepala Desa,Dinas Pendidikan dan Kebudayaan.

Berdasarkan hasil penelitian, permasalahan anak

Helda Rahmasari, Upaya Penanggulangan dan Perlindungan Hukum Terhadap Permasalahan Anak di Kota Bengkulu 
yang paling dominan di Kota Bengkulu adalah permasalahan anak terlantar dan anak jalanan, serta anak yang berhadapan dengan hukum (baik sebagai pelaku maupun sebagai korban tindak pidana). Anak-anak jalanan (street children) yang merupakan produk dinamika perkotaan marak di kota-kota besar Indonesia yang ironisnya tanpa perlindungan hukum, rawan dengan kekerasan, asumsi criminal (criminal image) dan destruktif bagi kemajuan kota. ${ }^{20}$

Berdasarkan Pasal 59 UU

No. 23 Tahun 2002 Jo UU No. 35 Tahun 2014 tentang Perlindungan Anak, menegaskan bahwa :

"Pemerintah dan lembaga Negara lainnya berkewajiban dan bertanggungjawab memberikan untuk khusus kepada anak dalam situasi darurat, anak yang berhadapan dengan hukum, anak dari kelompok minoritas dan terisolasi, anak tereksploitasi secara ekonomi dan/atau seksual, anak yang diperdagangkan, anak yang

20 Helda Rahmasari, Kebijakan Non Penal Dalam Penanggulangan Eksploitasi Seksual Komersial Terhadap Anak (Studi di Kota Surakarta), Tesis Mandirim Program Magister Ilmu Hukum Universitas Diponegoro, Semarang, 2005, hlm. 3.

Helda Rahmasari, Upaya Penanggulangan dan Perlindungan Hukum Terhadap Permasalahan Anak di Kota Bengkulu menjadi korban penyalahgunaan narkotika, alcohol, psikotropika, dan zat adiktif lainnya (napza), anak korban penculikan, penjualan dan perdagangan, anak korban kekerasan baik fisik dan/atau mental, anak yang menyandang cacat, dan anak korban perlakuan salah dan penelantaran"

Secara tegas pasal tersebut menyebutkan bahwa kewajiban dan tanggung jawab terhadap anak yang mengalami "masalah" tidak saja menjadi tanggung jawab orang tua dan keluarga namun dalam cakupan yang lebih luas. Negara dalam hal ini pemerintah memiliki kewajiban dan tanggung jawab besar dalam menanggulangi permasalahan anak yang terjadi.

Dalam menanggulangi permasalahan anak yang ada di Kota Bengkulu, upaya yang dilakukan instansi pemerintah terkait maupun LSM yang bergerak dalam bidang perlindungan anak, melalui tindakan preventif maupun represif. Barda Nawawi Arief mengungkapkan, bahwa :

"Beberapa masalah dan kondisi sosial yang dapat merupakan faktor kondusif penyebab timbulnya kejahatan jelas merupakan masalah yang 
tidak dapat diatasi semata-mata dengan jalur penal. Di sinilah letak keterbatasan jalur penal dan oleh karena itu harus ditunjang oleh jalur non penal". ${ }^{21}$

Upaya non penal terlihat dari upaya yang telah dilakukan oleh pihak-pihak terkait dalam bidang perlindungan anak di Kota Bengkulu sebagaimana hasil penelitian yang telah disebutkan sebelumnya baik melalui tindakan preventif maupun represif.

Upaya yang dilakukan oleh instansi terkait dalam hal perlindungan anak berdasarkan hasil penelitian ini belum maksimal, karena terkendala dengan biaya untuk melaksanakan program yang telah disusun. Dalam hal ini penulis mencoba membuat suatu model untuk menanggulangi permasalahan anak yang terjadi di Kota Bengkulu terutama permasalahan anak jalanan, melalui penelitian lebih lanjut yang dilaksanakan pada tahun 2017. Model penanggulangan yang ditawarkan yaitu dengan membuat sebuah SOP (Standar

21 Barda Nawawi Arief, Bunga Rampai Kebijakan Hukum Pidana, Citra Aditya Bakti, Bandung, 2002, hlm.46. Helda Rahmasari, Upaya Penanggulangan dan Perlindungan Hukum Terhadap Permasalahan Anak di Kota Bengkulu

Operasional Prosedur) mengenai alur penanggulangan permasalahan anak jalanan, hal ini dilakukan melalui kerjasama antar instansi terkait di mana salah satu langkah yang diambil dengan mengaktifkan kembali rumah singgah yang sempat terhenti kegiatannya sehingga memberikan wadah bagi anakanak jalanan yang ada di Kota Bengkulu untuk beraktivitas dan berkreatifitas.

\section{PENUTUP}

1. dari hasil penelitian yang dilakukan dapat disimpulkan bahwa permasalahan anak yang terjadi di Kota Bengkulu adalah anak terlantar, anak jalanan, Anak Berhadapan dengan Hukum, Anak Berkebutuhan Khusus (Disabilitas), anak gepeng, putus sekolah. Faktor yang menjadi penyebab permasalahan anak tersebut adalah faktor keluarga yaitu kurangnya kasih sayang orang tua, kurangnya pengawasan orang tua dan broken home. Faktor lainnya yaitu karena faktor ekonomi, faktor yang tak kalah 
pentingnya adalah karena faktor lingkungan, etnik, dan pergaulan.

2. Upaya yang dilakukan untuk mengatasi permasalahan tersebut adalah dengan melakukan koordinasi dengan instansi terkait dalam hal perlindungan anak, memberikan advokasi dan pendampingan bagi $\mathrm{ABH}$, memberikan pendidikan perempuan, membangun mekanisme perlindungan berbasis sekolah, melakukan pendidikan keaksaraan di LAPAS, dan turut serta dalam membuat kebijakan yang berkaitan tentang anak di Kota Bengkulu.

\section{DAFTAR PUSTAKA}

Barda Nawawi Arief, Bunga Rampai Kebijakan Hukum Pidana, PT. Citra Aditya Bakti, Bandung, 2002.

Darwan Prinst, Hukum Anak Indonesia, PT. Citra Aditya Bakti, Bandung, 2003.

Freddy Ferdinant Sanses, Tinjauan Yuridis-Sosiologis Pertanggungjawaban Pidana Pemerintah Kota Bengkulu dan Orangtua Dalam Penghapusan Eksploitasi
Ekonomi Terhadap Anak, skripsi Fakultas Hukum Universitas Bengkulu, 2015.

Helda Rahmasari, Kebijakan Non Penal Dalam Penanggulangan Eksploitasi Seksual Komersial Terhadap Anak (Studi di Kota Surakarta), Tesis Program Magister Ilmu Hukum Universitas Diponegoro, Semarang, 2005.

tumbuh kembang anak di wilayah pesisir kota bengkulu dalam perspektif undang-undang nomor 23 tahun 2002, Penelitian Dosen Pemula Fakultas Hukum Universitas Bengkulu, 2013.

pemerintah kota dalam penanggulangan keberadaan pekerja seks komersial (psk) dari kalangan pelajar di kota bengkulu (suatu kajian kebijakan dan kriminologi), Penelitian BOPTN Fakultas Hukum Universitas Bengkulu, 2014.

Laporan Kajian, Analisis Situasi Perlindungan Anak di Provinsi Bengkulu, Kerjasama antara Kementerian Pemberdayaan Perempuan dan Perllindungan Anak Republik Indonesia dan Pusat Studi Gender dan Keluarga Lembaga

Helda Rahmasari, Upaya Penanggulangan dan Perlindungan Hukum Terhadap Permasalahan Anak di Kota Bengkulu 
Penelitian dan Pengabdian

Kepada Masyarakat

Universitas Bengkulu, 2015.

Maulana Hassan Wadong,

Pengantar Advokasi dan

Hukum Perlindungan Anak,

Grasindo, Jakarta, 2000.

Muhammad Joni, dan Zulchaina

Z. Tanamas, Aspek Hukum

Perlindungan Anak dalam

Perspektif Konvensi Hak

Anak, PT. Citra Aditya

Bakti, Bandung, 1999.

Panduan Program Nasional Anak Indonesia (PNBAI) 2015, Kementerian Pemberdayaan Perempuan Republik Indonesia, Jakarta, 2004.

Supriyadi W. Eddyono, Pengantar Konvensi Hak Anak (Seri Bahan Bacaan Kursus Ham Untuk Pengacara), Lembaga Studi dan Advokasi Masyarakat, Jakarta, 2005.
Undang-Undang Perlindungan Anak (UU NO. 23 Th. 2002 Jo UU No. 35 Th. 2002 )

Undang-Undang Nomor 39 Th. 1999 tentang Hak Asasi Manusia, Sinar Grafika, Jakarta, 2000.

Bengkulu Ekspress 2 November 2015, Incest Bengkulu Peringkat Satu, diakses melalui http://bengkuluekspress.co $\underline{\mathrm{m} / \text { incest-bengkulu- }}$ peringkat-satu/, pada tanggal 16 Maret 2016

Wahyu Hartomo, (tanpa tahun), Rakornas Tumbuh Kembang Anak, Plt. Deputi Bidang Tumbuh Kembang Anak Kementerian Pemberdayaan Perempuan dan Perlindungan Anak, www.google.com, Tumbuh Kembang anak.

Helda Rahmasari, Upaya Penanggulangan dan Perlindungan Hukum Terhadap Permasalahan Anak di Kota Bengkulu 